\title{
Breve fra Armeen
}

af cand.mag. et phil. Martin Dyrbye

Der går næppe en dag uden avislæseren, radiolytteren eller TV-seeren konfronteres med krigsbegivenheder, og undertiden chokeres af billederne og kommentarerne. Ofte glemmes omstændighederne, hvorunder krigsereportagen bliver til. Dette forhold gjaldt således også i 1864, da Danmark led nederlag overfor Østrig-Preussen. Krigens følger for befolkningen og stemningen udødeliggjordes i dansk litteratur, da Herman Bang i 1889 skrev romanen "Tine", en kærlighedshistorie, hvori dagliglivet på Als under krigen skildredes virkelighedstro og følelsesfyldt.

Kontrasten mellem de, der oplevede krigen på nærmeste hold, kampene $\mathrm{i}$ Sønderjylland og ved Dybbøls skanser, og dem, der blot kendte til hændelsesforløbet fra aviserne, blev gjort tydelig i "Tine" gennem en af romanens bipersoner, "den sortsmudskede Korrespondent fra København", der leverede reportager til "Bladet", og som i Bangs skildring forekom mere sensationslysten end sympatisk. Ved læsningen af aviser fra krigen i 1864 nuanceres billedet af krigskorrespondenten, og hans rolle som nyhedsformidler.

Een af de mange, der leverede reportager fra Als, var forfatteren Carit Etlar, der unavngiven skrev en række "Breve fra Armeen" i vinteren 1864 til Berlingske Tidende. Året efter udkom novellerne "Krigsbilleder", hvori forfatteren i små historier gengav sine oplevelser fra krigene i 1848 og 1864.

I året 1853 blev Carit Etlar (hvis rigtige navn var Carl Brosbøll) ansat på det store kongelige Bibliothek under usædvanlige omstændigheder, idet han fik stillingen som amanuensis ved kongelig udnævnelse, takket være Frederik den Syvende, der imødekom et løfte, afgivet undet sit årlange ophold som kronprins i Fredericia, overfor Etlars fader, om fornødent at hjælpe hans børn. Ansættelsen af Etlar vakte dog ikke videre begejstring, hverken i Ministeriet for Kirke- og Undervisningsvæsenet eller på biblioteket, hvor forfatteren blandt kollegerne ofte følte sig som "den fremmede vilde Fugl, 
Carit Etlar (Carl Brosbøll), 18161900. Træsnit af H.P. Hansen, efter Monies' maleri fra 1865 , som idag findes opbevaret på Frederiksborg Museet.

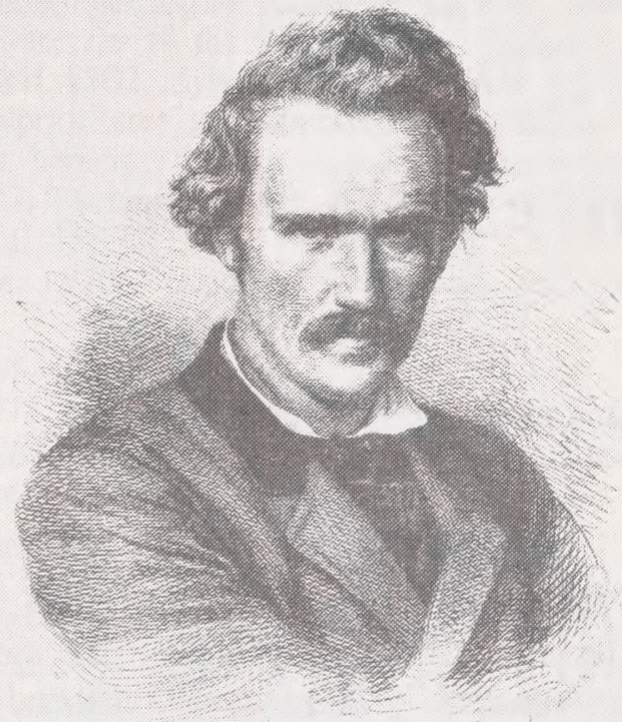

der ikke kunde tæmmes, og som havde andetsteds hjemme". Trods modstanden mod ansættelsen blev Etlar i 1858 udnævnt til inspektør ved udlånet, en stilling han besad indtil afskeden i 1885. Ved flere lejligheder påkaldte Etlar sig ledelsens vrede, hvilket følgende episode fra de dramatiske dage i vinteren 1864 viser.

Ikke uden vanskeligheder drog Etlar til fronten for at skrive, idet hans "Permission" fra biblioteket ikke skete med overbibliotekar Chr. Bruuns billigelse. I en brevveksling fra marts 1864 forklarede Etlar, at han ". . . havde aftalt med en Boghandler, at skrive ham en Krigshistorie, og ønskede i den Anledning at rejse nogle dage til Als". Efter i midten af februar 1864 at have bedt overbibliotekaren overveje at give rejsetilladelsen, havde Etlar, under "et Ærinde", forelagt sit ønske hos ministeren for Kirke- og Undervisningsvæsenet, C. Th. Engelstoft, som "greb denne Idee med en tilsyneladende interesse", og "tilstod", at han selv havde ønsket at faa Begivenhederne herovre fremstillede paa en mindre ensidig Maade, end hidtil, at Krigsministeren allerede havde talt med ham derom". Derpå blev Etlar bedt om at gå til krigsminister Lundbye. Før Etlar fik foretræde, var krigsministeren forinden orienteret som forfatterens ønske om "Permission", som blev imødekommet udenom den undrende overbibliotekar.

Forfatteren ville alene følge "sit eget Hoved", og ønskede ikke at påtage sig "nogen som helst bestemt Mission". Overfor sin chef fastholdt Etlar på det bestemteste, at han ikke rejste, for at "blive Correspondent for en Avis", 
selvom han af krigsministeren forsynedes med et "aabent Brev til den kommanderende General" og "et Pas", som indeholdt den fornødne tilladelse til at gøre ophold og få bolig på Als.

Den egentlige årsag til Etlars rejse var snarere at finde et andet sted, idet Berlingskes hidtidige korrespondent ved armeen, Hans Nansen Larsen, der mere end nogen anden i samtiden beherskede den politiske journalistik, måtte trække sig tilbage fra felten af helbredsmæssige årsager. Dette fik konseilspræsidenten D.G. Monrad til, af taktiske grunde, overfor Berlingskes redaktør Buchheister at træde i funktion som "Over-Redaktør", og udsende Etlar til Armeen.

Det var ej heller glemt, at forfatteren under treårskrigen havde gjort stor lykke med enakteren "Tonne gaaer i Krigen", opført i 1849 på Det kongelige Teater. I skuespillet viste Etlar sin foragt for de af danskerne i Slesvig, betegnet som "Insurgenter", der uden held skiftede side, alt efter krigslykkens gunst. Hertil kommer, at Etlar i mange af sine romaner på en utvetydig og ligefrem måde overfor sine mange læsere vedkendte sig sit patriotiske sindelag.

Flere år senere bekræftede Etlar, at han drog i "Felttoget, udsendt af Monrad for at skrive Artikler til "Berlingske Tidende". Dette forklarer til-

Trafningen ved Dybbøl den 17. marts 1864, gengivet i det franske blad "L'Illustration".

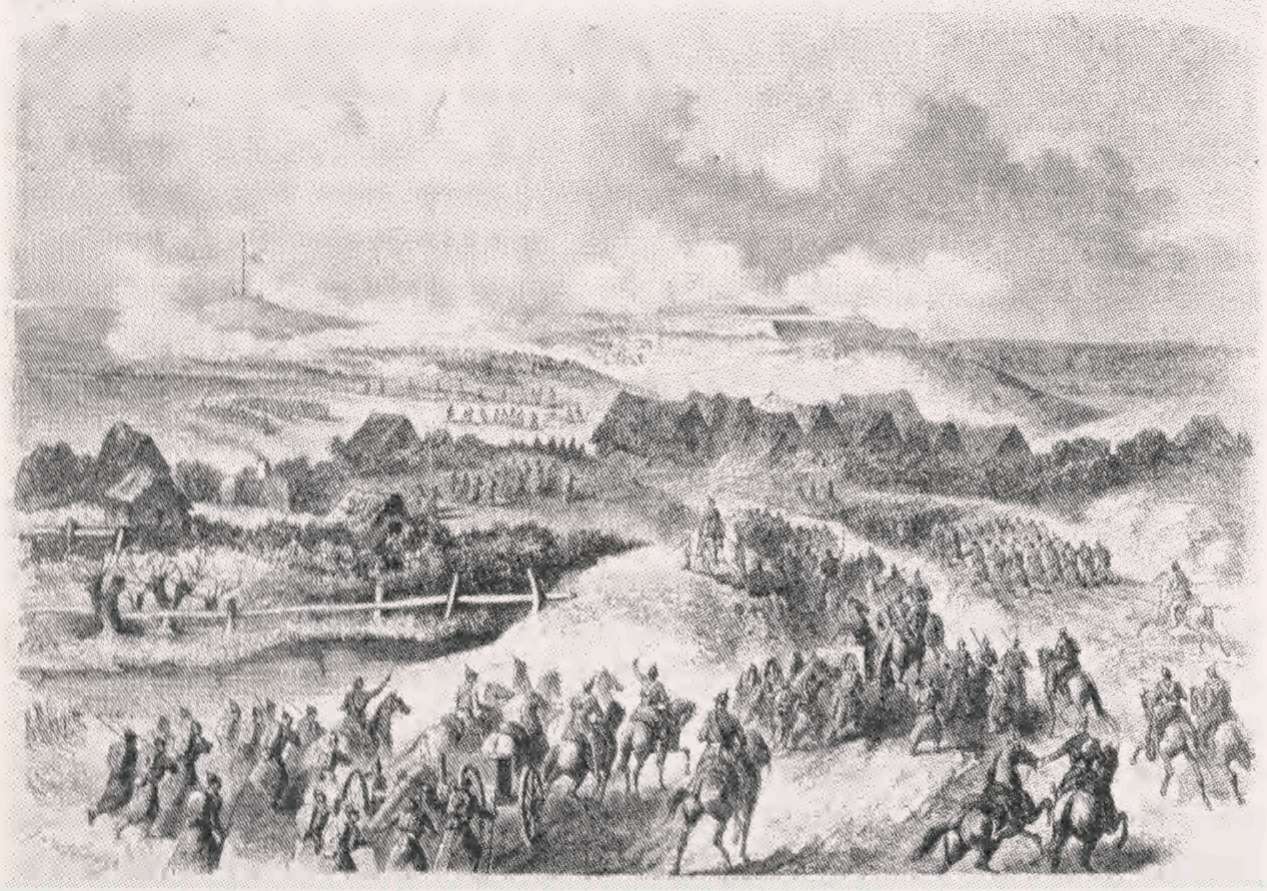


lige, at Monrad personligt lod Etlars orlov forlænge frem til efter den 18. april. Fra slutningen af februar og frem til april kunne Berlingskes læsere næsten daglig følge forfatterens "Breve fra Armeen". Enkelte blev endog citeret i danske og udenlandske blade. Navnlig to af artiklerne adskiller sig fra den $\emptyset$ vrige krigsreportage, ved fortrinsvis at berette om dagligdagen og stemningen på Als, - oftest i vemodig erindring om danskernes sejrsgang under treårskrigen.

En artikel, trykt den 29. februar 1864, under overskriften "Medens vi vente", indledte Etlar således:

"Det brogede Billede, Sønderborg i denne tid fremstiller, vil man ikke være istand til at gjøre sig nogen Forestilling om ovre hos Eder, og jeg skynder mig med at give en skildring deraf idag, fordi der muligviis imorgen ikke vil blive leilighed dertil; det trækker sammen omkring os; Alt i Himmel og paa Jord tyder paa et Uveir, ikke en af disse flygtige Byger, der glemmes efter at være overstaaede, men en af dem, hvis Spor bliver ved at præge Minde igjennem de kommende Tider, Mærker, der vel kunne blive til Ar, men selv som Ar endnu bestandig vidne om megen Manddom og store Bedrifter. Alt hvad der ellers betegne Byen og Kjøbstadslivet, er forsvundet, fortrængt. Borgeren og hans Hustru og Datter er fortrængte, enhver fredelig Skygge af Familielivet er fortrængt; det lugter af Krudt omkring os, og det syder og larmer og rasler og Alt giver Dig et Varsel om Kamp og Tilintetgjørelse. Fra ethvert Vindue stirrer et skægget Ansigt ned paa Dig, Du hører og seer kun Soldaten, gaaer afveien for en Krudtkarre for at støde paa en Brødvogn, undviger en Suppekjedel og falder i Armene på en Kjøddrager. I 1848 var der langt større Ungdom i dette Billede, mere Friskhed og svulmende Liv, det er som om ethvert Ansigt herovre er blevet ældre siden, større Alvor, færre Sange, flere Rynker og færre Smiil, mer Selvbevidsthed og et mindre sanguinsk Haab. Man gjør sig det smule Liv saa tungt, saa tungt, siger Poeten".

I de følgende dages "Breve" til avisen og private personer, lagde Etlar ikke skjul på, at han i lighed med adskillige andre korrespondenter havde lyst til at pakke kufferten og rejse hjem, idet krigen næppe kunne vindes måske kunne de kæmpende håbe på ". . . Lykken, men ikke forudsætte den for givet". På ingen måde havde Etlar noget tilovers for "Overkommandoens tørre og fordølgende Referater", idet han betragtede alt på "kortere Afstand", og havde indtrykkene "fra forrige Krig, Stemningen, og Begejstringen for Sagen, frisk indbrændt" i sin erindring.

Trods middelmådige angreb mod artiklerne, fortsatte Etlar med at skrive sine "Breve". Visse "Trequartblodsidioter", dele af de litterære kredse og Hovedstadspresse, kunne øjensynligt ikke forlige sig med forfatterens evne 


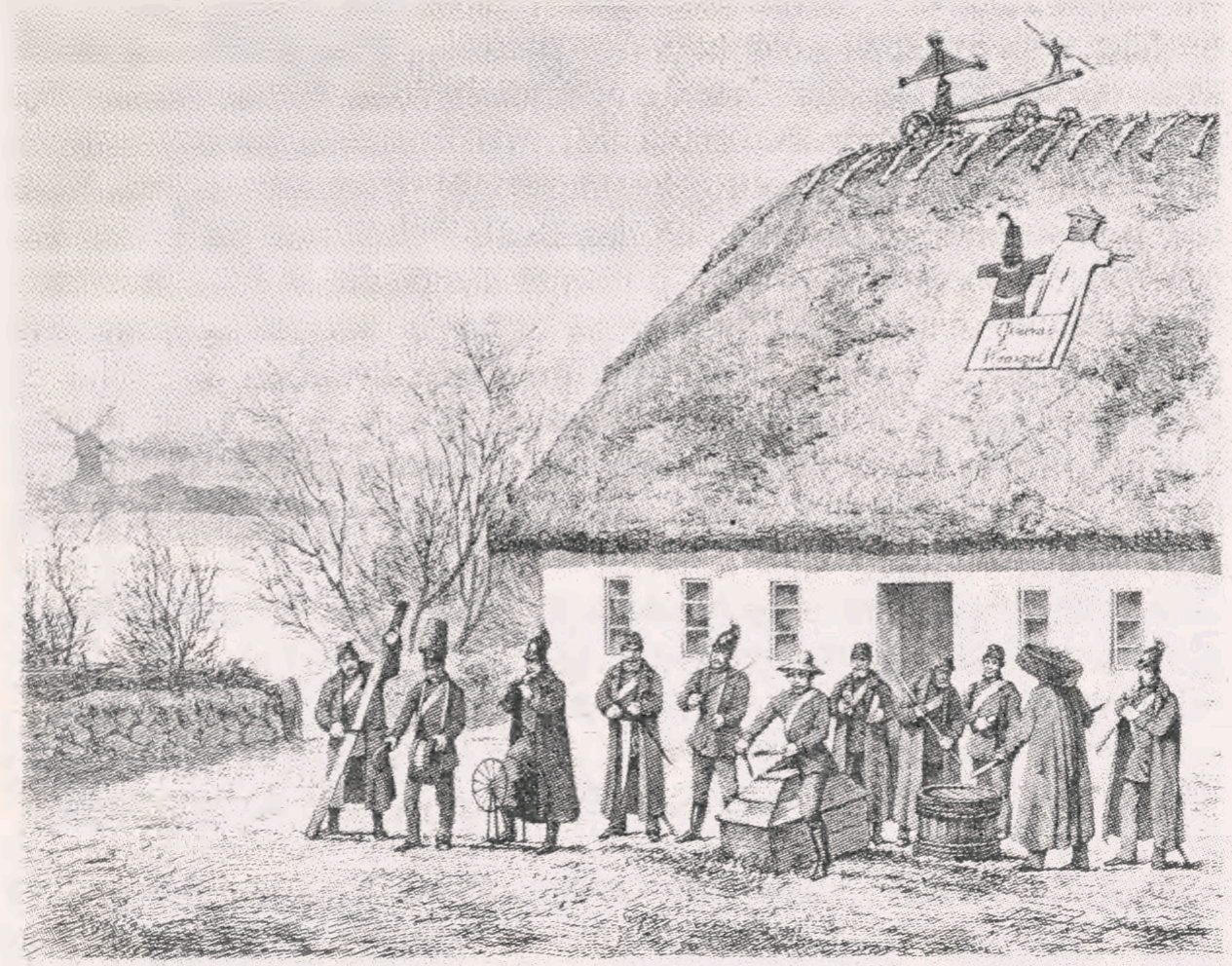

I sit brev den 15. marts 1864 til overbibliotekar Chr. Bruun skrev Carit Etlar bl.a.: "Skrive og piske sig op i en Stemning, som hvert kommende Budskab giør til Løgn, det er mit Arbeide, døm da selv, om det er Fornøielsen der holder mig tilbage her. Nu spiller Janitscharmusikken igjennem Gaderne. Det er ogsaa en stor Løgn, vi maa vist have vundet idag, fortælle Soldaterne hinanden." Illustrationen, "En musicerende Cavalleri-Piket i Øster-Dybbøl", blev bragt i 1864 i "To hundrede Træsnit", Danske historiske Blade. Tegneren kendes ikke.

til ved "Dialogformen", at skildre virkeligheden, medens andre kun formåede at agte "det Spændende", "det Novellistiske" og "det Modbydelige". I brevet "Et Kapitel om Dyrene", i Berlingske den 3. marts, blev forholdene beskrevet med dyrene som sindbillede på "Krigsbegivenhederne". Med en særegen ironi polemiserede Etlar mod de mange "forskjelligartede Skildringer af Tilstanden og det Passerede". Læserne måtte efterhånden være "temmelig paa det Rene med Alt", og artiklen fortsatte:

"Den ubetydeligste Krigsbegivenhed har fundet sin Historieskriver. Ulykken bar Flaget, på Vers endogsaa, Hungeren har vaandet sig og vist Tænder mod Intendanturen. Veiret er blevet refereret paa det Ubarmhjertigste, Phantasien er kommen Virkeligheden til hjælp, har smykket den med sine Farver, undertiden endog klattet temmelig tykt paa. Trods alt dette, har dog den danske Beskedenhed ingensinde fornægtet sig. Kampen ved Mysunde og 
ved Bustorp kaldte vi Rekognosceringer, medens vore Fjender ansaae dem for Slag, efter hvilke de holdt Lov- og Takkesange i deres Kirker og smykkede deres Feltherrer med Ordener og Udmærkelser. Arriere-kampen ved Overs $\emptyset$ har Overkommandoen kun funden Anledning til at omtale flygtigt og i Forbigaaende, medens Østerrigerne føre Beviis for, at der, forholdsviis til Kampens Længde og Tiden, hvori den forgik, faldt Flere end i Napoleon den Førstes blodigste Feltslag. Og hvorfor skulde vel alt dette ikke være blevet skildret som skeet er? Hvor er der en Dansk, stor eller lille, som ikke paa sin Maade maa være Deltager i denne Kamp, hvem har ikke sendt en Fader, en Broder, en Slægtning, en dyrebar Ven over til Dette blodige Stævne? Enhver Hilsen derfra maa altsaa interessere, og hvad skal den vel tage sig for Andet, end at skildre og fortælle, den store Kohort af Korrespondenter, af

Referenter og Skribenter og Recensenter, der

Hele den lange Dag maae gaae

Philosophisk op og ned ad Bakken.

Og ved hvert Træ lidt stille staae,

Og lytte efter Folks Discours og Snakken".

Billedet af samtidens "krigskorrespondent", set i perspektiv af Carit Etlars "Breve fra Armeen", medvirker ikke blot til at fremme forståelsen af dagliglivet ved skanserne i 1864, men viser tillige krigsreportagens mange facetter, akkurat som den opleves af læseren af dagens aviser, gennem radio og fjernsyn. 